Published in final edited form as:

ACS Biomater Sci Eng. 2016 February 8; 2(2): 268-277. doi:10.1021/acsbiomaterials.5b00534.

\title{
Biodegradable Elastomers with Antioxidant and Retinoid-like Properties
}

\author{
Robert van Lith ${ }^{\dagger, \#}$, Xuesong Wang ${ }^{\dagger, \#}$, and Guillermo Ameer ${ }^{\dagger, \ddagger, \S, \|, \perp,{ }^{*}}$ \\ †Biomedical Engineering Department, Northwestern University, Evanston, Illinois 60208, United \\ States \\ ‡Department of Surgery, Feinberg School of Medicine, Chicago, Illinois 60611, United States \\ $\S$ Chemistry of Life Processes Institute, Northwestern University, Evanston, Illinois 60208, United \\ States \\ "Simpson Querrey Institute for BioNanotechnology in Medicine, Northwestern University, Chicago, \\ Illinois 60611, United States \\ ${ }^{\perp}$ International Institute for Nanotechnology, Northwestern University, Evanston, Illinois 60208, \\ United States
}

\section{Abstract}

Intimal hyperplasia $(\mathrm{IH})$ is a type of scarring that involves complex pathophysiological responses of the vasculature to injury, including overproliferation and migration of vascular smooth muscle cells (VSMCs), adventitial fibroblasts, and the activation of macrophages. The objective of this research was to develop a biodegradable polymer with intrinsic properties that would combat the cellular processes that contribute to IH. Citric acid, 1,8-octanediol, and all-trans retinoic acid (atRA) were incorporated into a polyester network via a condensation reaction to form the thermoset poly(1,8-octamethylene-citrate-co-retinate) (POCR). POCR was chemically characterized and assessed for the presence of antioxidant and retinoidlike properties. ${ }^{\mathrm{H}} \mathrm{NMR}$ and ATR-FTIR confirmed the incorporation of atRA into the backbone of the polymer network. POCR was able to scavenge radicals and inhibit lipid peroxidation. The proliferation and migration of vascular smooth muscle cells cultured on POCR were inhibited, whereas endothelial cell proliferation and migration were not. These results are consistent with the biological effects of atRA. These results are the first to demonstrate the synthesis of a polymer with intrinsic antirestenotic properties for potential use in the fabrication of vascular devices such as stents and vascular grafts.

\footnotetext{
*Corresponding Author. g-ameer@ northwestern.edu.

\#These authors contributed equally.

ASSOCIATED CONTENT

Supporting Information

The Supporting Information is available free of charge on the ACS Publications website at DOI: 10.1021/acsbiomaterials.5b00534.

Mechanical properties, antioxidant properties of free atRA, additional polymer characterization, cell morphologies (PDF)

Author Contributions

The manuscript was written through contributions of all authors. All authors have given approval to the final version of the manuscript.

The authors declare no competing financial interest.
} 


\section{Graphical Abstract}

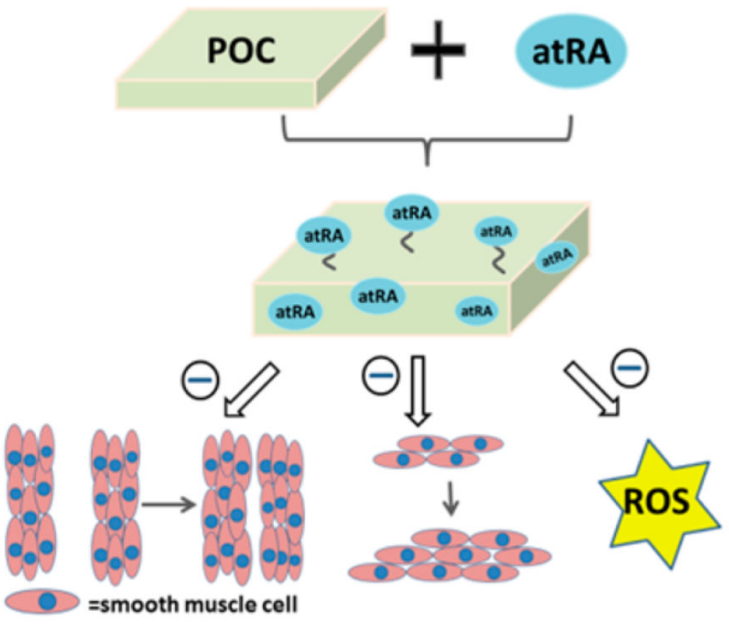

\section{Keywords}

all-trans retinoic acid; elastomer; citric acid; intimal hyperplasia; vitamin A

\section{INTRODUCTION}

Cardiovascular disease continues to be the leading cause of death and disability in the United States. ${ }^{1}$ Current options for surgical interventions include angioplasty with or without stent placement, revascularization via bypass vascular grafts, and endarterectemy. Successful long-term outcomes for these procedures are often hindered by restenosis due to the formation of intimal hyperplasia (IH) in the vessel. ${ }^{2-5} \mathrm{IH}$ is a type of scarring that involves complex pathophysiological responses of the vasculature to injury, including overproliferation and migration of vascular smooth muscle cells (VSMCs), adventitial fibroblasts, and the activation of macrophages. Although paclitaxel, rapamycin, and their analogues have been used to prevent VSMC overproliferation, an ideal therapeutic agent would selectively inhibit the above cellular processes, without affecting endothelial cell survival, proliferation, and function to promote the regeneration of a healthy blood vessel wall.

All-trans retinoic acid (atRA), the active form of vitamin A, is known to have agonistic interactions with nuclear receptors RARa and RXR to modulate the expression of target genes that regulate cellular proliferation, migration, and differentiation. ${ }^{6-9}$ It also has been reported to be a chain-breaking antioxidant. ${ }^{10}$ atRA is used clinically to treat pathologies characterized by abnormal cell differentiation such as in acute promyelocytic leukemia (APL), acne vulgaris, and keratosis pilaris. ${ }^{11-14}$ Due to its ability to inhibit VSMC proliferation, promote VSMC apoptosis, promote endothelial cell proliferation, ${ }^{15}$ and promote NO production, ${ }^{16,17}$ it has also been investigated as a systemic or localized therapy to inhibit IH with promising results in animal studies. ${ }^{18-20}$ However, although atRA has been proven to be relatively safe clinically, systemic administration in humans is not feasible 
because according to preclinical data, the doses that would be required to inhibit IH are approximately 30 -fold higher than what is currently utilized to treat cancers in patients. ${ }^{21}$ Furthermore, systemic doses have been shown to elevate triglycerides and alkaline phosphatase levels. ${ }^{12,20}$ Localized exposure of atRA via a periadventitial membrane achieved a significant reduction of IH in a rat carotid balloon injury model, but these devices are designed for use during open surgery and hence not intended for endovascular surgical procedures, which account for the majority of cardiovascular procedures in the U.S. Therefore, strategies to incorporate the biological effects of atRA into endovascular devices and small-diameter prosthetic vascular grafts are desirable.

The overproliferation and migration of vascular cells is partially regulated by the oxidative stress in cells and tissues. ${ }^{22-25}$ Oxidative stress is an imbalance between the antioxidant defense system and levels of reactive oxygen species (ROS) that can cause damage to proteins, DNA, and signaling pathways. As such, oxidative stress has been implicated in a multitude of pathologies, including diabetes and cardiovascular disease. ${ }^{26,27}$ Vascular interventions can damage the blood vessel leading to local inflammation and the accumulation of excess ROS. Furthermore, nitric oxide (NO), a multifunctional and antioxidant regulator that is necessary for healthy vasculature, is often absent due to a missing or impaired endothelial cell monolayer. The resulting oxidative stress has been shown to trigger overproliferation of VSMC. ${ }^{23,24}$ These effects are further exacerbated when polymers such as poly(L-lactic acid) (PLLA) and poly(glycolic acid) (PGA) are used in medical devices that are placed in the vasculature, because their degradation products can induce oxidative stress. ${ }^{28,29}$

Given the need for improved vascular stents and prosthetic vascular grafts, the development of polymers that will not induce oxidative stress and are capable of tackling key cellular processes that contribute to IH is warranted. In this regard, the field of biomaterials science has evolved to include biofunctionality as a key design parameter that is important to meet the challenging specifications of medical devices, technologies, and therapeutics of the $21 \mathrm{st}$ century. Traditionally, polymers have served as structurally inert components of devices that, depending on the intended use, are engineered to be permanent or to degrade in the body. In the case of degradable polymers such as PLLA and PGA, a common area of clinical use and research has been the encapsulation and slow release of drugs in order to minimize deleterious systemic side effects and maximize the desired response of the target tissue or organ. An example that is relevant to cardiovascular medicine is the drug eluting stent.

Although the physical incorporation of drugs into polymers has been met with some clinical success, the polymers used do not have intrinsic biofunctionality and only serve as a means for delivery of a therapeutic drug dose to obtain a pharmacological effect. Herein, we describe the synthesis and characterization of citrate-based biodegradable polymers with built in antioxidant and retinoid-like functionality aimed at minimizing cellular processes that exacerbate an artery's response to injury. These polymers could potentially be used for the fabrication of stents and prosthetic vascular grafts, or to modify the surface of vascular grafts and other implantable medical devices whose function may be impaired by the development of IH. We hypothesized that an antioxidant polymer with retinoid-like functionality could be synthesized by covalently incorporating atRA into a cross-linked polymer network containing citric acid and 1,8-octanediol, resulting in a poly $(1,8$ 
octamethylene citrate-co-retinate) (POCR) thermoset copolymer. We further hypothesized that the degradation products of POCR would include atRA and/or its esters, thereby retaining inhibitory effects on smooth muscle cell proliferation and migration in vitro without negatively affecting endothelial cell proliferation.

\section{MATERIALS AND METHODS}

\subsection{Materials and Instrumentation}

All the chemicals and reagents are from Sigma-Aldrich and were used without further processing except where mentioned specifically. HPLC analysis was performed on a SPD-20A (Shimadzu, Kyoto, Japan) using an Ascentis RP Amide column $(2.7 \mu \mathrm{m} ; 150 \mathrm{~mm}$ $\times 2.1 \mathrm{~mm}$; Supelco, Bellefonte, PA). FTIR was performed on a Nicolet Nexus 870 spectrometer (Thermo Scientific, Waltham, MA), ${ }^{\mathrm{H}} \mathrm{NMR}$ on an Inova 500 (Varian, Palo Alto, CA), and absorbance measurements on a Safire micro plate reader (Tecan, Mannedorf, Switzerland). Solvent evaporation was performed on an R-205 rotavapor (Buchi, Flawil, Switzerland).

\subsection{Polymer Synthesis}

Poly(1,8-octamethylene-citrate-co-retinate) (POCR) was synthesized using a modification to the protocol previously described for the synthesis of poly(1,8-octamethylenecitrate) (POC) prepolymer (prePOC) ${ }^{30}$ Briefly, citric acid and 1,8-octanediol at a molar ratio of 1:1 were copolymerized via polycondensation in a three-neck round-bottom flask at $160{ }^{\circ} \mathrm{C}$ for 15 min, followed by $60 \mathrm{~min}$ at $140{ }^{\circ} \mathrm{C}$. The prepolymer was then dissolved in $100 \%$ ethanol and purified by precipitation in Milli-Q water at a volume ratio of 1:5. The purified prepolymer was freeze-dried and redissolved in $100 \%$ ethanol at $30 \%$ w/w. For POCR synthesis, prePOC (10\% or $30 \% \mathrm{w} / \mathrm{w}$ in EtOH) was mixed with atRA at a final concentration of 1 or 4 $\mathrm{mg} / \mathrm{mL}$ atRA, resulting in POCR-4 and POCR-16 with 4 and $16 \mu \mathrm{g}$ of atRA/mg of polymer, respectively. Subsequently, POCR was postpolymerized at 37 or $60{ }^{\circ} \mathrm{C}$ for 5 or 20 days (Scheme 1). POC, synthesized and postpolymerized without the addition of atRA, was used as a reference material.

\subsection{Polymer Characterization}

To assess whether atRA was copolymerized and integrated in the polymer's backbone or dispersed throughout the polymer, Fourier Transform Infrared (FTIR) spectroscopy was used in attenuated total reflection mode on POC and POCR-16 polymers postpolymerized for 2 days or 5 days at $60{ }^{\circ} \mathrm{C}$. Spectra were recorded by accumulation of 64 scans, with a resolution of $8 \mathrm{~cm}^{-1}$. Polymer films were used after gas sterilization, acid leaching, and lyophilization (see section 2.5.1), without further treatment. FTIR of free atRA was also collected using transmission mode with atRA incorporated into $\mathrm{KBr}$ pellets. ${ }^{\mathrm{H}} \mathrm{NMR}$ was performed on atRA as well as the viscous polymer product in DMSO- $d_{6}$ after 2 days of postpolymerization at $60^{\circ} \mathrm{C}$ to determine atRA incorporation. The mechanical properties of POC, POCR-4, and POCR-16 were assessed through tensile tests according to American Society for Testing and Materials (ASTM) 412A on an Instron 5544 equipped with a 500-N load cell (Instron, Norwood, MA). Briefly, dumbbell-shaped samples were pulled to failure 
at a rate of $500 \mathrm{~mm} / \mathrm{min}$. Young's modulus, ultimate tensile strength, and elongation at break were obtained from stress-strain curves.

\section{4. atRA Release from POCR}

To assess structural retention of atRA after postpolymerization, atRA release from POCR-16 was monitored over time. High-performance liquid chromatography (HPLC) was performed in accordance with a method previously reported. ${ }^{31}$ Briefly, POCR polymers were incubated in $1: 1$ ratio Milli-Q water and acetonitrile $(50 \mathrm{mg} / \mathrm{mL})$ at $37^{\circ} \mathrm{C}$. Supernatant containing polymer releasate was collected every 2 days and replaced with fresh Milli-Q/acetonitrile solution. Samples were injected into an Ascentis RP-Amide column $(15 \mathrm{~cm} \times 2.1 \mathrm{~mm}, 3$ $\mu \mathrm{m})$. Separation of product was obtained through a gradient solvent system using water (solvent A) and acetonitrile (solvent B) at flow rate of $0.4 \mathrm{~mL} / \mathrm{min}$ (gradient: 0-3 min, hold at $70 \% \mathrm{~B} ; 3-15 \mathrm{~min}, 70-95 \% \mathrm{~B} ; 15-20 \mathrm{~min}$, hold at $95 \% \mathrm{~B} ; 20-21 \mathrm{~min}, 5-70 \% \mathrm{~B} ; 21-25$ min, re-equilibrate at $70 \% \mathrm{~B}$ ) over $25 \mathrm{~min}$. The atRA peak was monitored through a UV-vis detector at a wavelength of $350 \mathrm{~nm}$. Peak area was compared to a standard curve of freshly prepared atRA. HPLC analysis was also utilized to determine structure retention as a measure of bioactivity according to a previously described method. The absence of an atRAspecific peak at the elution time of 13.3 min was indicative of structural loss. ${ }^{31}$

\subsection{Intrinsic Antioxidant Activity}

2.5.1. Polymer Preparation-For all antioxidant assays, the following preparation protocol was used. Tissue culture plastic (TCP) plates (96-well) were coated with $40 \mu \mathrm{L}$ per well of $30 \%$ w/w polymer solutions in EtOH. Experimental groups included POCR prepared with 1 and $4 \mathrm{mg} / \mathrm{mL}$ atRA in ethanol, resulting in POCR-4 and POCR-16 with 4 and $16 \mu \mathrm{g}$ atRA/mg polymer, respectively. Other groups included $\mathrm{POC}$ alone and poly $(1,8-$ octamethylene-citrate-co-ascorbate) (POCA), a POC variant which we previously showed to have enhanced antioxidant properties. ${ }^{32}$ After evaporating the ethanol, coated well plates were postpolymerized at $60{ }^{\circ} \mathrm{C}$ for 5 days. After ethylene oxide gas sterilization for $12 \mathrm{~h}$ (Anprolene AN74i, Andersen Products, HawRiver, NC), polymers were acid-leached with DMEM cell culture basal media as per a previously published protocol ${ }^{32}$ Briefly, media were changed every day until no discoloration was observed for $24 \mathrm{~h}$. Plates were then washed with Milli-Q water three times and lyophilized before use.

2.5.2. Free Radical Scavenging - POCR free radical scavenging activity was performed using a (1,1-diphenyl-2-picrylhydrazyl) (DPPH) free radical assay. To each well, $200 \mu \mathrm{L}$ of DPPH ( $200 \mu \mathrm{M}$ in ethanol) was added, and plates were incubated at $37{ }^{\circ} \mathrm{C}$ (final polymer concentration $50 \mathrm{mg} / \mathrm{mL}$ ). Supernatants were collected at predetermined time points. DPPH is a stable free radical in EtOH with a deep violet color. Upon radical scavenging activity by the antioxidant material, a color change to pale yellow will be observed. This discoloration was monitored by measuring the absorbance change at $517 \mathrm{~nm}$ using a micro plate reader. Antioxidant activity in terms of scavenging DPPH free radicals was calculated as scavenging percentage of DPPH radical by measuring the decrease of absorbance compared to nonreacted solution and fully reacted solution. All measurements were performed in triplicate. 
2.5.3. Iron Chelation-The extent of metal chelation was performed using a ferrous iron chelation assay. To each polymer-coated well, $200 \mu \mathrm{L}$ of $\mathrm{FeCl}_{2} \cdot 4 \mathrm{H}_{2} \mathrm{O}$ solution ( $1 \mathrm{mM}$ in MQ) was added and incubated at $37{ }^{\circ} \mathrm{C}$ (final polymer concentration $50 \mathrm{mg} / \mathrm{mL}$ ).

Supernatants were collected and reacted with $5 \mathrm{mM}$ ferrozine iron reagent solution at a volume ratio of 5:1. Chelating activity is indicated by inhibition of the purple $\mathrm{Fe}^{2+}-$ ferrozine complex formation, as chelated $\mathrm{Fe}^{2+}$ cannot react with ferrozine. The inhibition can be monitored as a decrease in absorbance at $534 \mathrm{~nm}$. Chelation is calculated as a percentage of decreased absorbance compared to a no-chelation control. All measurements were taken in triplicate.

2.5.4. Lipid Peroxidation Inhibition-POCR's lipid peroxidation inhibition capacity was determined by performing a $\beta$-carotene bleaching assay according to a previously published protocol. ${ }^{32}$ Briefly, $\beta$-carotene $(4 \mathrm{mg})$, linoleic acid $(0.5 \mathrm{~mL})$ and tween $40(4 \mathrm{~g})$ were mixed, dissolved in chloroform $(20 \mathrm{~mL})$, and vigorously shaken. This step was followed by chloroform evaporation using rotary evaporation, resulting in a viscous $\mathrm{BC}$ reagent. Britton buffer ( $\mathrm{pH} 6.5$, prewarmed to $45^{\circ} \mathrm{C}$ ) was added (30 to $1 \mathrm{~mL} \mathrm{BC}$ reagent) to form a clear suspension. A total of $200 \mu \mathrm{L}$ of the suspension was added to each coated well and incubated at $45{ }^{\circ} \mathrm{C}$ (final polymer concentration $50 \mathrm{mg} / \mathrm{mL}$ ). Supernatants were collected at various time points and the absorbance monitored at $470 \mathrm{~nm}$. Spontaneous peroxidation of linoleic acid at $45^{\circ} \mathrm{C}$ causes $\beta$-carotene discoloration, and inhibition of linoleic acid peroxidation can be detected as a reduction in absorbance decrease. All measurements were performed in triplicate.

\subsection{Cell Viability, Proliferation, and Migration}

2.6.1. Plate Preparation and Pretreatment-For all cell culture experiments, tissue culture polystyrene (TCP) plates were prepared as in section 2.5.1, with POCR-4 and POCR-8 having atRA concentrations of 4 and $8 \mu \mathrm{g} / \mathrm{mg}$ polymer, respectively. However, before cell seeding, wells were pretreated for 1 day with the complete growth media for each cell type investigated (EGM-2 and SmGM-2 for human umbilical vein endothelial cells (HUVECs) and human aortic smooth muscle cells (HASMCs), respectively). For migration experiments, 24-well plates coated with $200 \mu \mathrm{L}$ per well of the polymer solution were used.

2.6.2. Cell Cytotoxicity, Proliferation, and Migration-The bioactivity of POCR was assessed using HUVECs and HASMCs (Lonza, Walkersville, MD) that were within passage 4-7. To assess cell toxicity, cells were seeded in the pretreated 96-well plates at a seeding density of 5000 cells $/ \mathrm{cm}^{2}$. After $48 \mathrm{~h}$ of culture, the LIVE/DEAD viability kit (Life Technologies, Carlsbad, CA) was used according to the manufacturer's instructions to measure the ethidium homodimer and calcein staining of dead and live cells, respectively.

For cell proliferation measurements, HUVECs and HASMCs were seeded in the pretreated 96-well plates. HUVECs were seeded at $3000 \mathrm{cells} / \mathrm{cm}^{2}$, and HaSMCs were seeded at 5000 cells $/ \mathrm{cm}^{2}$. Cell lysates were collected at 1, 3, and 5 days for measurement of DNA content using the PicoGreen dsDNA quantitation reagent (Life Technologies, Carlsbad, CA). Briefly, cells were rinsed with PBS three times, and $100 \mu \mathrm{L}$ of cell lysis buffer containing $1 \%$ Triton X-100 were added to each well. After 15 min of incubation at room temperature, 
$50 \mu \mathrm{L}$ of cell lysate was collected from each well. Cell lysates were mixed with PicoGreen at a 1:1 volume ratio. To measure the cell number, a standard curve was generated using known cell numbers in culture and their corresponding fluorescence intensity.

For cell migration measurements, a scratch migration test was performed. HUVECs and HASMCs were seeded in pretreated 24-well plates. Upon reaching $100 \%$ confluence, cells were serum-starved with basal media for $12 \mathrm{~h}$ (HUVECs with EBM-2, HASMCs with SmBM-2). Subsequently, a vertical scratch was made in each well, cells washed with prewarmed PBS and cells cultured for another $24 \mathrm{~h}$ in basal media. The remaining scratched area was measured using ImageJ software to determine the in vitro effect on cell migration.

\subsection{Modification of ePTFE Grafts with POCR and Assessment of Antioxidant Activity}

ePTFE grafts (inner diameter, $1.96 \pm 0.05 \mathrm{~mm}$; wall thickness, $240 \pm 35 \mu \mathrm{m}$; ZEUS, Branchburg, NJ) were coated with POCR solutions (10\% w/w in EtOH with 0, 1, or 4 $\mathrm{mg} / \mathrm{mL}$ atRA) using an infusion coating method, resulting in final polymer percentage of approximately $20 \%$ as reported previously. ${ }^{32}$ After coating and ethanol evaporation, the grafts were postpolymerized at $60{ }^{\circ} \mathrm{C}$ for 5 days. Before antioxidant tests, ethylene oxide gas sterilization and acid leaching were performed, followed by rinsing with Milli-Q water. Free radical scavenging, iron chelation, and lipid peroxidation tests were all performed on coated and intact grafts using $100 \mathrm{mg}$ grafts per milliliter in all assays.

\subsection{Statistical Analysis}

Statistical analysis was performed using Microsoft Excel software and Graphpad Prism 5.0 (Graphpad Software Inc., USA). Data from independent experiments were quantified and analyzed for each variable. Comparisons between two treatments were made using student's $t$ test (two tail, unequal variance) and comparisons between multiple treatments were made using analysis of variance (ANOVA), with Bonferroni posthoc analysis. A value of $p<0.05$ was considered to be statistically significant, with additional significance levels used of $p<$ 0.01 and $p<0.001$.

\section{RESULTS AND DISCUSSION}

\subsection{Polymer Synthesis}

atRA has limited solubility in aqueous media, and it is known to be sensitive to light, heat, and air in solution. ${ }^{33}$ To ensure its chemical integration into the elastomers while retaining stability and activity, conditions for atRA incorporation were optimized. The objective was to determine the maximum amount of atRA possible per weight of polymer; therefore the maximal soluble concentration of $4 \mathrm{mg} / \mathrm{mL}$ of atRA in EtOH was used. POC was dissolved either at $10 \%$ or $30 \% \mathrm{w} / \mathrm{w}$ in EtOH. It was observed that at a $10 \% \mathrm{w} / \mathrm{w}$ POC solution, atRA recrystallized out of solution when added at a concentration of $4 \mathrm{mg} / \mathrm{mL}$, which led to inhomogeneous polymer films at both 37 and $60{ }^{\circ} \mathrm{C}$ conditions. Hence, POC prepolymer in solution increases atRA solubility in $\mathrm{EtOH}$, possibly due to the citric acid, a known enhancer of coconstituent solubility for drugs. ${ }^{34-37}$ When using a $30 \% \mathrm{w} / \mathrm{w}$ POC solution for subsequent testing, two different temperatures for postpolymerization were used, 37 and $60{ }^{\circ} \mathrm{C}$. For $37^{\circ} \mathrm{C}$, a postpolymerization time of 20 days was needed to obtain a cross-linked 
elastomer, while for $60^{\circ} \mathrm{C}$, a cross-linked elastomer was obtained in 5 days. For films postpolymerized at $37{ }^{\circ} \mathrm{C}$ for 20 days, the structure and activity of atRA was lost as assessed per HPLC analysis ${ }^{31}$ likely due to long-term exposure to elevated temperature and air. Therefore, all subsequent experiments were performed with $30 \% \mathrm{w} / \mathrm{w}$ polymer solutions containing a maximum atRA concentration of $4 \mathrm{mg} / \mathrm{mL}$, postpolymerized at $60{ }^{\circ} \mathrm{C}$ for 5 days (Table 1).

\subsection{Polymer Characterization}

Polymer releasates analyzed by HPLC showed a peak at a retention time of $13.3 \mathrm{~min}$, which was consistent with the peak obtained with a freshly prepared atRA solution used to generate the standard curve. The appearance of a peak at the expected retention time of 13.3 min confirms the preservation of atRA's structure after postpolymerization. No peaks associated with 9-cis RA or 13-cis RA were observed. Cumulative release of atRA from POCR-16 shows steady, near zero-order kinetics for atRA release with only $0.4 \%$ released as free atRA after 15 days. These results suggest that the vast majority of atRA remains as part of the POCR covalent network or is released in the form of cooligomers with citric acid and 1,8-octanediol (Figure 1).

FTIR analysis of partially polymerized POCR-16 and POC films showed the presence of small peaks in the $1540-1650 \mathrm{~cm}^{-1}$ region, indicating $\mathrm{C}=\mathrm{C}$ bonds of atRA (Figure 2). Free atRA has a strong peak around $1690 \mathrm{~cm}^{-1}$ due to $-\mathrm{COOH}$ moieties. ${ }^{38}$ Upon esterification, this peak disappears and shifts to $1730 \mathrm{~cm}^{-1}$ and is obscured by the polyester $\mathrm{C}=\mathrm{O}$ stretch also present in POC. A minor peak around $1690 \mathrm{~cm}^{-1}$ remains in POCR-16 after 2 days of postpolymerization, indicating that atRA remains partially unconjugated to POC. After complete postpolymerization, only minor peaks related to atRA's $\mathrm{C}=\mathrm{C}$ bonds can be observed in POCR-16, but there is no remaining peak around $1690 \mathrm{~cm}^{-1}$ (Supporting Information S3A). A strong peak at $1190 \mathrm{~cm}^{-1}$ (polyester $\mathrm{C}-\mathrm{O}$ ) can also be observed in both POC and POCR.

Proton NMR analysis confirmed the successful incorporation of atRA into the poly(1,8octamethylene-citrate) network in POCR-16. The following peaks were identified (Figure 3): $\delta 7.00\left(-\mathrm{CH}=\mathrm{CH}-\mathrm{C}\left(\mathrm{CH}_{3}\right)=\mathrm{CH}-\mathrm{CH}=\mathrm{CH}-\mathrm{C}\left(\mathrm{CH}_{3}\right)=\mathrm{CHCO}-\right), 6.37(-\mathrm{CH}=\mathrm{CH}-$ $\left.\mathrm{C}\left(\mathrm{CH}_{3}\right)=\mathrm{CHCO}-\right), 5.75\left(-\mathrm{C}\left(\mathrm{CH}_{3}\right)=\mathrm{CHCO}-\right), 2.25\left(-\mathrm{C}\left(\mathrm{CH}_{3}\right)=\mathrm{CHCO}-\right), 1.96\left(\mathrm{C}-\mathrm{CH}_{2}-\right.$ $\left.\mathrm{C}\left(\mathrm{CH}_{3}\right)=\mathrm{C}\right), 1.67\left(\mathrm{C}=\mathrm{C}\left(\mathrm{CH}_{3}\right)-\mathrm{C}\right)$, and $0.993\left(-\mathrm{C}\left(\mathrm{CH}_{3}\right)_{2}\right.$ of the cyclohexenyl ring are all attributed to atRA. From POC, the following peaks were also identified: $\delta 1.15$ ($\mathrm{OCH}_{2} \mathrm{CH}_{2}\left(\mathrm{CH}_{2}\right)_{4}$ - from OD), 1.50 (- $\mathrm{OCH}_{2} \mathrm{CH}_{2}\left(\mathrm{CH}_{2}\right)_{4}$ - from OD), 2.50-2.90 (-OCO$\mathrm{CH} 2-\mathrm{C}(\mathrm{OH})(\mathrm{COOH})-$ from $\mathrm{CA}), 3.36\left(-\mathrm{CH}_{2} \mathrm{O}-\right.$ from $\left.\mathrm{OD}\right), 3.57$ (-( $\left.\mathrm{HOOC}\right) \mathrm{C}(\mathrm{OH})-$ from $\mathrm{CA}), 3.60\left(-\mathrm{CH}_{2} \mathrm{OH}\right.$ from $\left.\mathrm{OD}\right)$, and 3.95 (-( $\left.\mathrm{HOOC}\right)-\mathrm{C}(\mathrm{OH})-$ from $\left.\mathrm{CA}\right)$. Integration of peaks $\mathrm{A}$ and $\mathrm{B}$ (octanediol), $\mathrm{E}$ (citric acid), and 8 (atRA) gives approximate final ratios of 0.47:0.49:0.005, which indicates a $0.92 \mathrm{w} / \mathrm{w} \%$ atRA in final POCR-16. The absence of atRA's carboxylic acid-specific peak at $12.0 \mathrm{ppm}$ (11 in Figure 3A) together with FTIR results confirm the esterification of atRA into the POCR structure (see Supporting Information S3B for close-up of POCR-spectrum around $12.0 \mathrm{ppm}) .{ }^{39,40}$ Mechanical testing confirmed that POC and POCR polymers were elastomeric and that atRA incorporation had 
no significant effect on Young's modulus or ultimate tensile strength (Supporting Information S2).

\subsection{Intrinsic Antioxidant Activity}

atRA's effects on VSMCs, such as the inhibition of cell migration and proliferation, may be partly ascribed to its redox-active status. As a typical redox compound, atRA is expected to be antioxidant at lower concentrations and pro-oxidant at high concentrations. However, reports on suitable ranges for antioxidant effects are largely inconsistent. For example, atRA has previously been reported to behave as an antioxidant at physiological concentrations in the nanomolar range, while in the micromolar supraphysiological range, it may actually induce oxidative stress and behave as a pro-oxidant compound. ${ }^{41,42}$ Siddikuzzaman and Grace, on the other hand, recently measured direct radical scavenging and lipid peroxidation inhibition at concentrations above $16.7 \mu \mathrm{M} .{ }^{43}$ The concentration of POC, POCR- 4 , and POCR-16 in antioxidant assays here was $50 \mathrm{mg} / \mathrm{mL}$, which according to NMR data corresponds to an atRA loading of 0.115 and $0.460 \mathrm{mg} / \mathrm{mL}$, respectively. Considering the release rate observed in Figure 1, free atRA concentrations after $24 \mathrm{~h}$ would reach approximately $0.1-0.4 \mu \mathrm{M}$. However, nonreleased atRA or atRA released as conjugates with POC oligomers may also be able to exhibit antioxidant activity. POCR exhibited a concentration-dependent gradual scavenging effect on the DPPH radical (Figure 4A). DPPH scavenging of $100 \%$ was achieved after 45, 21, and $6 \mathrm{~h}$ for POC, POCR4, and POCR-16, respectively. Similar to observations reported by Siddikuzzaman and Grace, we also observed gradual DPPH scavenging by atRA (Supporting Information Figure S1A). Radical scavenging was concentration-dependent, showing proportionality of atRA availability with its feed ratio (Figure 4A). Hence, POCR antioxidant capacity may be controlled by adjusting the feed ratio of atRA to POC prepolymer during the postpolymerization step. As reported previously, POC also exhibits free radical scavenging properties, possibly due to cyclic oligomer species. ${ }^{32}$

Citric acid is a well-known iron chelating agent. Iron is a transition metal that plays an important role in cell regulatory processes, and excessive amounts can cause oxidative stress, e.g., by participating in the Fenton reaction to produce the highly damaging hydroxyl radical. ${ }^{44-47}$ Moreover, transition metals can potentially react with antioxidant compounds such as ascorbic acid. ${ }^{48,49}$ Neglecting to include chelating agents has therefore been proposed to be a potential source of negative or ineffective results from major antioxidant supplementation clinical trials, and coadministration of EDTA or citric acid has been suggested.$^{50}$ For atRA, it has been shown that potential pro-oxidant effects at higher concentrations can be attenuated or even eliminated by metal chelators. ${ }^{41}$ For these reasons, the use of citric-acid-rich POC was expected to minimize prooxidant effects of incorporated or released atRA. Both POC and POCR showed strong iron chelating activity as expected likely due to the presence of citric acid in the polymer backbone (Figure 4B). No differences were observed among all polydiolcitrates, suggesting that the incorporation of compounds that can copolymerize through ester bond formation with free diol groups in the polydiolcitrate network does not interfere with citric acid's ability to chelate metal ions. 
A typical effect of excessive reactive oxygen species (ROS) or oxidative stress in tissues is the peroxidation of lipids, e.g., in atherosclerotic plaques, which can lead to functional impairment. The inhibition of this process by compounds, such as antioxidants, is therefore typically measured in addition to direct radical scavenging effects. As a useful in vitro assay, the $\beta$-carotene bleaching assay measures the inhibition of linoleic acid peroxidation when exposed to $45^{\circ} \mathrm{C}$. POC was shown previously to inhibit this process, ${ }^{32}$ while free atRA can also dose-dependently prevent beta carotene bleaching (Supporting Information S1C). Indeed, POCR demonstrated greater lipid peroxidation inhibition than POC (Figure 4C) with no inhibition observed by ePTFE. After 2 and $3 \mathrm{~h}$ of heat exposure, we could also observe a significant difference between POCR-16 and POCR-4. After $2 \mathrm{~h}$, the last time point before $100 \%$ peroxidation was reached in the control groups, beta carotene bleaching was inhibited by $23.7 \pm 0.6 \%, 26.7 \pm 0.4 \%$, and $32.5 \pm 0.7 \%$ for POC, POCR- 4 , and POCR-16, respectively. The trend of increased antioxidant activity with increasing atRA concentrations in the polymer demonstrates the potential to tune the antioxidant activity of the resulting polymer.

\subsection{Antioxidant Activity of POCR-coated ePTFE Grafts}

As the anticipated initial application for POCR would be as an antirestenotic polymer platform for improving vascular healing after surgical interventions, as a proof of concept, a commercially available ePTFE graft was coated with POCR to assess the feasibility of using POCR to modify the surface functionality of a medical device. Infusion coating resulted in a polymer content of $27.6 \pm 6.5 \mathrm{wt} \%$ in coated grafts, which kept node-fibril structure largely intact (Figure 5A-C). In the polymer-coated grafts, radical scavenging and inhibition of lipid peroxidation remained significant. As previously reported by our group, POC as well as other polydiolcitrates exhibit modest antioxidant activity likely due to the formation of cyclic oligomer structures within the polymer network. ${ }^{32,51}$ The incorporation of atRA however leads to significantly increased antioxidant capacity even at low atRA concentrations. Nonetheless, the concentration dependence of DPPH scavenging disappeared (Figure 5D), which may be due to hydrophobic ePTFE allowing easier penetration of hydrophobic DPPH, causing a saturation effect at the lower atRA concentration. In terms of lipid peroxidation inhibition, grafts coated with both POCR-4 and POCR-16 showed effects exceeding those of POC, with a $13.4 \pm 5.1 \%$ and $44.9 \pm 15.4 \%$ decrease in peroxidation after $2 \mathrm{~h}$ for POCR-4 and POCR-16, respectively, although the decrease in POCR-4 did not reach statistical significance (Figure 5E). All together, these results indicate the feasibility of using POCR as a coating material to create antioxidant surfaces for vascular applications.

\subsection{Cell Viability, Proliferation, and Migration}

atRA has previously been reported to potentially have toxic effects at higher concentrations, typically in the micromolar range of concentrations. ${ }^{41,43,52}$ As POCR contains up to $0.92 \mathrm{wt}$ $\%$ atRA in our experiments (according to NMR results), this could create potentially a toxic environment for cells in contact with the polymer. Culture of both HUVECs and HASMCs on POCR, however, did not result in significant cell death, as assessed through calcein AM and ethidium homodimer staining (Figure 6). Although there appears to be a slight decrease in viability of both cell types when cultured on POCR, this decrease did not reach statistical 
significance. Based on our HPLC measurements of atRA release from POCR, when using 96-well plates coated with $10 \mathrm{mg}$ polymer/well, free atRA concentrations are expected to not exceed $0.8 \mu \mathrm{M}$ during our experiments.

atRA has been reported to inhibit cell proliferation in glioma, breast cancer, smooth muscle, and epithelial cells. ${ }^{9,53-55}$ This inhibitory effect is part of its appeal for applications in cancer and cosmetic areas, and also for deploying atRA after vascular interventions to limit neointimal hyperplasia. ${ }^{18-20}$ Our lab has reported cell proliferation effects of atRA consistent with antioxidant properties at micromolar concentrations. ${ }^{19}$ Reported inconsistencies could partially be explained by cell-specific effects. For example, reports of micromolar pro-oxidant effects of atRA were measured in Sertoli cells, cells that are known to have macrophage-type effects and therefore may be more prone to rapid ROS generation as part of their phenotypical tendencies. ${ }^{41}$ Therefore, vascular cell-specific effects of POCR on cell proliferation were assessed. Cell proliferation was assessed with cells cultured on POCR. Proliferation was selectively stunted in HASMCs only on POC, as reported before. ${ }^{32,56}$ On the polymers with the highest atRA incorporation, however, both cell types were significantly lower in number after 3 days of cell culture, with a $20.7 \pm 3.0 \%$ and 19.4 $\pm 1.8 \%$ reduction for HUVECs and HASMCs, respectively. After 5 days, the amount of HASMCs was reduced by $14.1 \pm 1.2 \%$ on POCR- 8 , while that of HUVECs was not significantly lower. POCR-8 inhibited cell proliferation for both HUVECs and HASMCs compared to POC after 5 days, with a $11.2 \pm 1.2 \%$ and $9.0 \pm 0.7 \%$ lower cell number, respectively (Figure 7A and B). POCR-4 did not show a significant effect on cell proliferation compared to POC. An atRA-concentration dependent inhibitory effect on HASMC proliferation reached significance after 5 days.

As a first step to assess the retinoid-like properties of POCR that are relevant to a potentially antirestenotic polymer, the effect of POCR on the proliferation and differentiation of HUVECs and HASMCs were determined. An in vitro scratch assay was used to simulate a wound healing response. This assay measures the ability of cells to bridge a defined gap that is created. To exclude gap closure due to cell proliferation, basal media lacking serum components was used. HASMC migration on POC, POCR-4, and POCR-8 surfaces led to $40.5 \pm 8.0 \%, 85.3 \pm 20.2 \%$, and $96.8 \pm 24.5 \%$ of the gap area remaining when normalized to TCP, respectively (Figure 7C). Therefore, incorporation of atRA into POC resulted in an enhanced inhibitory effect on HASMC migration. In contrast, HUVECs cultured on POC and POCR surfaces closed the gap area at similar rates, irrespective of percentage of atRA (Figure 7D). Our findings regarding the inhibition of HASMCs migration on POCR with no differential effect on HUVEC proliferation are consistent with previous studies. ${ }^{19}$

\section{CONCLUSIONS}

In summary, we have synthesized an antioxidant elastomer with retinoid-like properties that may be suitable for use in medical devices such as vascular stents and prosthetic vascular grafts that would benefit from the use of antirestenotic materials. Sustained release of bioactive atRA was demonstrated, with POCR having a slight effect on cell proliferation and selectively inhibiting HASMC migration without significantly affecting cellular viability. POCR films also demonstrated enhanced antioxidant properties compared to POC, with 
increased free radical scavenging and lipid peroxidation inhibition. ePTFE vascular grafts coated with POCR also exhibited antioxidant activity. Combined, these findings lay the groundwork for a new class of polymers with antirestenotic properties that exhibit antioxidant and retinoid-like biological effects.

\section{Supplementary Material}

Refer to Web version on PubMed Central for supplementary material.

\section{Acknowledgments}

This work was funded in part by the McCormick Research Catalyst Awards Fund and grant R01 EB017129-03 from the National Institutes of Health. NMR was performed at IMSERC Center at Northwestern University supported by the National Science Foundation CHE-9871268 and FTIR at the Keck-II facility of the NUANCE Center at Northwestern University. The NUANCE Center is supported by the International Institute for Nanotechnology, MRSEC (NSF DMR-1121262), the Keck Foundation, the State of Illinois, and Northwestern University.

\section{ABBREVIATIONS}

$\begin{array}{ll}\text { ATRA } & \text { all-trans retinoic acid } \\ \text { POC } & \text { poly(octamethylene citrate) } \\ \text { POCR } & \text { poly(octamethylene citrate-co-retinate) } \\ \text { IH } & \text { intimal hyperplasia } \\ \text { HUVEC } & \text { human umbilical vein endothelial cell } \\ \text { HASMC } & \text { human aortic smooth muscle cell } \\ \text { DPPH } & \text { 1,1-diphenyl-2-picrylhydrazyl } \\ \text { ROS } & \text { reactive oxygen species } \\ \text { IH } & \text { intimal hyperplasia } \\ \text { VSMC } & \text { vascular smooth muscle cell } \\ \text { ePTFE } & \text { expanded polytetrafluoroethylene }\end{array}$

\section{REFERENCES}

1. Go AS, Mozaffarian D, Roger VL, Benjamin EJ, Berry JD, Borden WB, Bravata DM, Dai S, Ford ES, Fox CS, Franco S, Fullerton HJ, Gillespie C, Hailpern SM, Heit JA, Howard VJ, Huffman MD, Kissela BM, Kittner SJ, Lackland DT, Lichtman JH, Lisabeth LD, Magid D, Marcus GM, Marelli A, Matchar DB, McGuire DK, Mohler ER, Moy CS, Mussolino ME, Nichol G, Paynter NP, Schreiner PJ, Sorlie PD, Stein J, Turan TN, Virani SS, Wong ND, Woo D, Turner MB. Heart Disease and Stroke Statistics-2013 Update: A Report From the American Heart Association. Circulation. 2013; 127:e6-e245. [PubMed: 23239837]

2. Hamon M, Bauters C, McFadden EP, Wernert N, Lablanche JM, Dupuis B, Bertrand ME. Restenosis after coronary angioplasty. Eur. Heart J. 1995; 16(Suppl I):33-48. [PubMed: 8829956]

3. Holmes DR Jr. In-stent restenosis. Reviews in cardiovascular medicine. 2001; 2(3):115-119. [PubMed: 12439375] 
4. Klinkert P, Post PN, Breslau PJ, van Bockel JH. Saphenous vein versus PTFE for above-knee femoropopliteal bypass. A review of the literature. European journal of vascular and endovascular surgery: the official journal of the European Society for Vascular Surgery. 2004; 27:357-362.

5. Klinkert P, Schepers A, Burger DH, van Bockel JH, Breslau PJ. Vein versus polytetrafluoroethylene in above-knee femoropopliteal bypass grafting: five-year results of a randomized controlled trial. Journal of vascular surgery. 2003; 37:149-155. [PubMed: 12514593]

6. Bouterfa H, Picht T, Kess D, Herbold C, Noll E, Black PM, Roosen K, Tonn JC. Retinoids inhibit human glioma cell proliferation and migration in primary cell cultures but not in established cell lines. Neurosurgery. 2000; 46:419-430. [PubMed: 10690732]

7. Braakhuis BJ, Klaassen I, van der Leede BM, Cloos J, Brakenhoff RH, Copper MP, Teerlink T, Hendriks HF, van der Saag PT, Snow GB. Retinoid metabolism and all-trans retinoic acid-induced growth inhibition in head and neck squamous cell carcinoma cell lines. Br. J. Cancer. 1997; 76:189197. [PubMed: 9231918]

8. Favennec L, Cals MJ. The biological effects of retinoids on cell differentiation and proliferation. Clin. Chem. Lab. Med. 1988; 26:479-489.

9. Lu J, Zhang F, Zhao D, Hong L, Min J, Zhang L, Li F, Yan Y, Li H, Ma Y, Li Q. ATRA-inhibited proliferation in glioma cells is associated with subcellular redistribution of beta-catenin via upregulation of Axin. J. Neuro-Oncol. 2008; 87:271-277.

10. Palace VP, Khaper N, Qin Q, Singal PK. Antioxidant potentials of vitamin A and carotenoids and their relevance to heart disease. Free Radical Biol. Med. 1999; 26:746-761. [PubMed: 10218665]

11. DiGiovanna JJ, Mauro T, Milstone LM, Schmuth M, Toro J. Systemic retinoids in the management of Ichthyoses and related skin types. Dermatologic therapy. 2013; 26:26. [PubMed: 23384018]

12. Fenaux P, Wang ZZ, Degos L. Treatment of acute promyelocytic leukemia by retinoids. Current topics in microbiology and immunology. 2007; 313:101-128. [PubMed: 17217041]

13. Tang XH, Gudas LJ. Retinoids, retinoic acid receptors, and cancer. Annu. Rev. Pathol.: Mech. Dis. $2011 ; 6: 345-364$.

14. Thielitz A, Gollnick H. Topical retinoids in acne vulgaris: update on efficacy and safety. American journal of clinical dermatology. 2008; 9:369-381. [PubMed: 18973403]

15. Herdeg C, Oberhoff M, Baumbach A, Schroeder S, Leitritz M, Blattner A, Siegel-Axel DI, Meisner C, Karsch KR. Effects of local all-trans-retinoic acid delivery on experimental atherosclerosis in the rabbit carotid artery. Cardiovasc. Res. 2003; 57:544-553. [PubMed: 12566127]

16. Achan V, Tran CT, Arrigoni F, Whitley GS, Leiper JM, Vallance P. all-trans-Retinoic acid increases nitric oxide synthesis by endothelial cells: a role for the induction of dimethylarginine dimethylaminohydrolase. Circ. Res. 2002; 90:764-769. [PubMed: 11964368]

17. Uruno A, Sugawara A, Kanatsuka H, Kagechika H, Saito A, Sato K, Kudo M, Takeuchi K, Ito S. Upregulation of nitric oxide production in vascular endothelial cells by all-trans retinoic acid through the phosphoinositide 3-kinase/Akt pathway. Circulation. 2005; 112:727-736. [PubMed: 16043647]

18. DeRose JJ Jr, Madigan J, Umana JP, Prystowsky JH, Nowygrod R, Oz MC, Todd GJ. Retinoic acid suppresses intimal hyperplasia and prevents vessel remodeling following arterial injury. Cardiovascular surgery (London, England). 1999; 7:633-639.

19. Gregory EK, Webb AR, Vercammen JM, Flynn ME, Ameer GA, Kibbe MR. Periadventitial atRA citrate-based polyester membranes reduce neointimal hyperplasia and restenosis after carotid injury in rats. American journal of physiology Heart and circulatory physiology. 2014; 307:H1419-H1429. [PubMed: 25239800]

20. Miano JM, Kelly LA, Artacho CA, Nuckolls TA, Piantedosi R, Blaner WS. all-Trans-retinoic acid reduces neointimal formation and promotes favorable geometric remodeling of the rat carotid artery after balloon withdrawal injury. Circulation. 1998; 98:1219-1227. [PubMed: 9743514]

21. Douer D, Zickl LN, Schiffer CA, Appelbaum FR, Feusner JH, Shepherd L, Willman CL, Bloomfield CD, Paietta E, Gallagher RE, Park JH, Rowe JM, Wiernik PH, Tallman MS. All-trans retinoic acid and late relapses in acute promyelocytic leukemia: very long-term follow-up of the North American Intergroup Study I0129. Leuk. Res. 2013; 37:795-801. [PubMed: 23528262] 
22. Clempus RE, Griendling KK. Reactive oxygen species signaling in vascular smooth muscle cells. Cardiovasc. Res. 2006; 71:216-225. [PubMed: 16616906]

23. Satoh K, Nigro P, Berk BC. Oxidative stress and vascular smooth muscle cell growth: a mechanistic linkage by cyclophilin A. Antioxid. Redox Signaling. 2010; 12:675-682.

24. Shimokawa H. Reactive Oxygen Species Promote Vascular Smooth Muscle Cell Proliferation. Circ. Res. 2013; 113:1040-1042. [PubMed: 24115068]

25. Yasunari K, Maeda K, Minami M, Yoshikawa J. HMG-CoA reductase inhibitors prevent migration of human coronary smooth muscle cells through suppression of increase in oxidative stress. Arterioscler., Thromb., Vasc. Biol. 2001; 21:937-942. [PubMed: 11397700]

26. Bonomini F, Tengattini S, Fabiano A, Bianchi R, Rezzani R. Atherosclerosis and oxidative stress. Histol. Histopathol. 2008; 23:381-390. [PubMed: 18072094]

27. Giacco F, Brownlee M. Oxidative stress and diabetic complications. Circ. Res. 2010; 107:10581070. [PubMed: 21030723]

28. Abbott DA, Suir E, Duong GH, de Hulster E, Pronk JT, van Maris AJ. Catalase overexpression reduces lactic acid-induced oxidative stress in Saccharomyces cerevisiae. Applied and environmental microbiology. 2009; 75:2320-2325. [PubMed: 19251894]

29. Selvam S, Kundu K, Templeman KL, Murthy N, Garcia AJ. Minimally invasive, longitudinal monitoring of biomaterial-associated inflammation by fluorescence imaging. Biomaterials. 2011; 32:7785-7792. [PubMed: 21813173]

30. Yang J, Webb AR, Ameer GA. Novel Citric Acid-Based Biodegradable Elastomers for Tissue Engineering. Adv. Mater. 2004; 16:511-516.

31. Kane MA, Folias AE, Napoli JL. HPLC/UV quantitation of retinal, retinol, and retinyl esters in serum and tissues. Anal. Biochem. 2008; 378:71-79. [PubMed: 18410739]

32. van Lith R, Gregory EK, Yang J, Kibbe MR, Ameer G. Engineering biodegradable polyester elastomers with antioxidant properties to attenuate oxidative stress in tissues. Biomaterials. 2014; 35:8113-8122. [PubMed: 24976244]

33. Hubinger JC. Determination of retinol, retinyl palmitate, and retinoic acid in consumer cosmetic products. Int. J. Cosmet. Sci. 2010; 32:236-500.

34. Evrard B, Chiap P, DeTullio P, Ghalmi F, Piel G, Van Hees T, Crommen J, Losson B, Delattre L. Oral bioavailability in sheep of albendazole from a suspension and from a solution containing hydroxypropyl- $\beta$-cyclodextrin. J. Controlled Release. 2002; 85:45-50. http://dx.doi.org/10.1016/ S0168-3659(02)00270-5.

35. Masuda T, Yoshihashi Y, Yonemochi E, Fujii K, Uekusa H, Terada K. Cocrystallization and amorphization induced by drug-excipient interaction improves the physical properties of acyclovir. Int. J. Pharm. 2012; 422:160-169. http://dx.doi.org/10.1016/j.ijpharm.2011.10.046. [PubMed: 22079714]

36. Nie S, Pan W, Li X, Wu X. The Effect of Citric Acid Added to Hydroxypropyl Methylcellulose (HPMC) Matrix Tablets on the Release Profile of Vinpocetine. Drug. Dev. Ind. Pharm. 2004; 30:627-635. [PubMed: 15285336]

37. Singh S, Parikh T, Sandhu HK, Shah NH, Malick AW, Singhal D, Serajuddin AT. Supersolubilization and amorphization of a model basic drug, haloperidol, by interaction with weak acids. Pharm. Res. 2013; 30:1561-1573. [PubMed: 23430485]

38. Rockley, NL.; Rockley, MG.; Halley, BA.; Nelson, EC. Methods in Enzymology. Vol. 123. Academic Press; 1986. [11] Fourier transform infrared spectroscopy of retinoids; p. 92-101.

39. Varshosaz J, Hassanzadeh F, Sadeghi Aliabadi H, Nayebsadrian M, Banitalebi M, Rostami M. Synthesis and Characterization of Folate-Targeted Dextran/Retinoic Acid Micelles for Doxorubicin Delivery in Acute Leukemia. BioMed. Res. Int. 2014; 2014:1-14.

40. Varshosaz J, Hassanzadeh F, Sadeghi H, Andalib S. Synthesis of octadecylamine-retinoic acid conjugate for enhanced cytotoxic effects of 5-FU using LDL targeted nanostructured lipid carriers. Eur. J. Med. Chem. 2012; 54:429-438. http://dx.doi.org/10.1016/j.ejmech.2012.05.024. [PubMed: 22687440]

41. da Frota MLC Jr, da Silva EG, Behr GA, de Oliveira MR, Dal-Pizzol F, Klamt F, Moreira JC. Alltrans retinoic acid induces free radical generation and modulate antioxidant enzyme activities in rat sertoli cells. Mol. Cell. Biochem. 2006; 285:173-179. [PubMed: 16479320] 
42. Dal-Pizzol F, Klamt F, Frota ML Jr, Moraes LF, Moreira JC, Benfato MS. Retinol supplementation induces DNA damage and modulates iron turnover in rat Sertoli cells. Free Radical. Res. 2000; 33:677-687. [PubMed: 11200098]

43. Siddikuzzaman, Grace VM. Antioxidant potential of all-trans retinoic acid (ATRA) and enhanced activity of liposome encapsulated ATRA against inflammation and tumor-directed angiogenesis. Immunopharmacol. Immunotoxicol. 2013; 35:164-173. [PubMed: 23116338]

44. Day SM, Duquaine D, Mundada LV, Menon RG, Khan BV, Rajagopalan S, Fay WP. Chronic iron administration increases vascular oxidative stress and accelerates arterial thrombosis. Circulation. 2003; 107:2601-2606. [PubMed: 12732602]

45. Kell DB. Iron behaving badly: inappropriate iron chelation as a major contributor to the aetiology of vascular and other progressive inflammatory and degenerative diseases. BMC. Med. Genomics. 2009; 2:2. [PubMed: 19133145]

46. Reeder BJ, Hider RC, Wilson MT. Iron chelators can protect against oxidative stress through ferryl heme reduction. Free Radical Biol. Med. 2008; 44:264-273. [PubMed: 18215735]

47. Saigo K, Kono M, Takagi Y, Takenokuchi M, Hiramatsu Y, Tada H, Hishita T, Misawa M, Imoto S, Imashuku S. Deferasirox reduces oxidative stress in patients with transfusion dependency. J. Clin. Med. Res. 2013; 5:57-60. [PubMed: 23390477]

48. Buettner GR, Jurkiewicz BA. Catalytic metals, ascorbate and free radicals: combinations to avoid. Radiat. Res. 1996; 145:532-541. [PubMed: 8619018]

49. Halliwell B. Vitamin C: antioxidant or pro-oxidant in vivo? Free Radical. Res. 1996; 25:439-454. [PubMed: 8902542]

50. Bauchner H, Fontanarosa PB, Golub RM. Evaluation of the trial to assess chelation therapy (tact): The scientific process, peer review, and editorial scrutiny. JAMA. 2013; 309:1291-1292. [PubMed: 23532245]

51. Yang J, van Lith R, Baler K, Hoshi RA, Ameer GA. A Thermoresponsive Biodegradable Polymer with Intrinsic Antioxidant Properties. Biomacromolecules. 2014; 15:3942-3952. [PubMed: 25295411]

52. Penniston KL, Tanumihardjo SA. The acute and chronic toxic effects of vitamin A. Am. J. Clin. Nutr. 2006; 83:191-201. http://ajcn.nutrition.org/content/83/2/191.long. [PubMed: 16469975]

53. Axel DI, Frigge A, Dittmann J, Runge H, Spyridopoulos I, Riessen R, Viebahn R, Karsch KR. Alltrans retinoic acid regulates proliferation, migration, differentiation, and extracellular matrix turnover of human arterial smooth muscle cells. Cardiovasc. Res. 2001; 49:851-862. [PubMed: 11230985]

54. Kosaka C, Sasaguri T, Komiyama Y, Takahashi H. All-trans retinoic acid inhibits vascular smooth muscle cell proliferation targeting multiple genes for cyclins and cyclin-dependent kinases. Hypertens. Res. 2001; 24:579-588. [PubMed: 11675954]

55. Van heusden J, Wouters W, Ramaekers FC, Krekels MD, Dillen L, Borgers M, Smets G. All-transretinoic acid metabolites significantly inhibit the proliferation of MCF-7 human breast cancer cells in vitro. Br. J. Cancer. 1998; 77:26-32. [PubMed: 9459142]

56. Hoshi RA, Van Lith R, Jen MC, Allen JB, Lapidos KA, Ameer G. The blood and vascular cell compatibility of heparin-modified ePTFE vascular grafts. Biomaterials. 2013; 34:30-41. [PubMed: 23069711] 


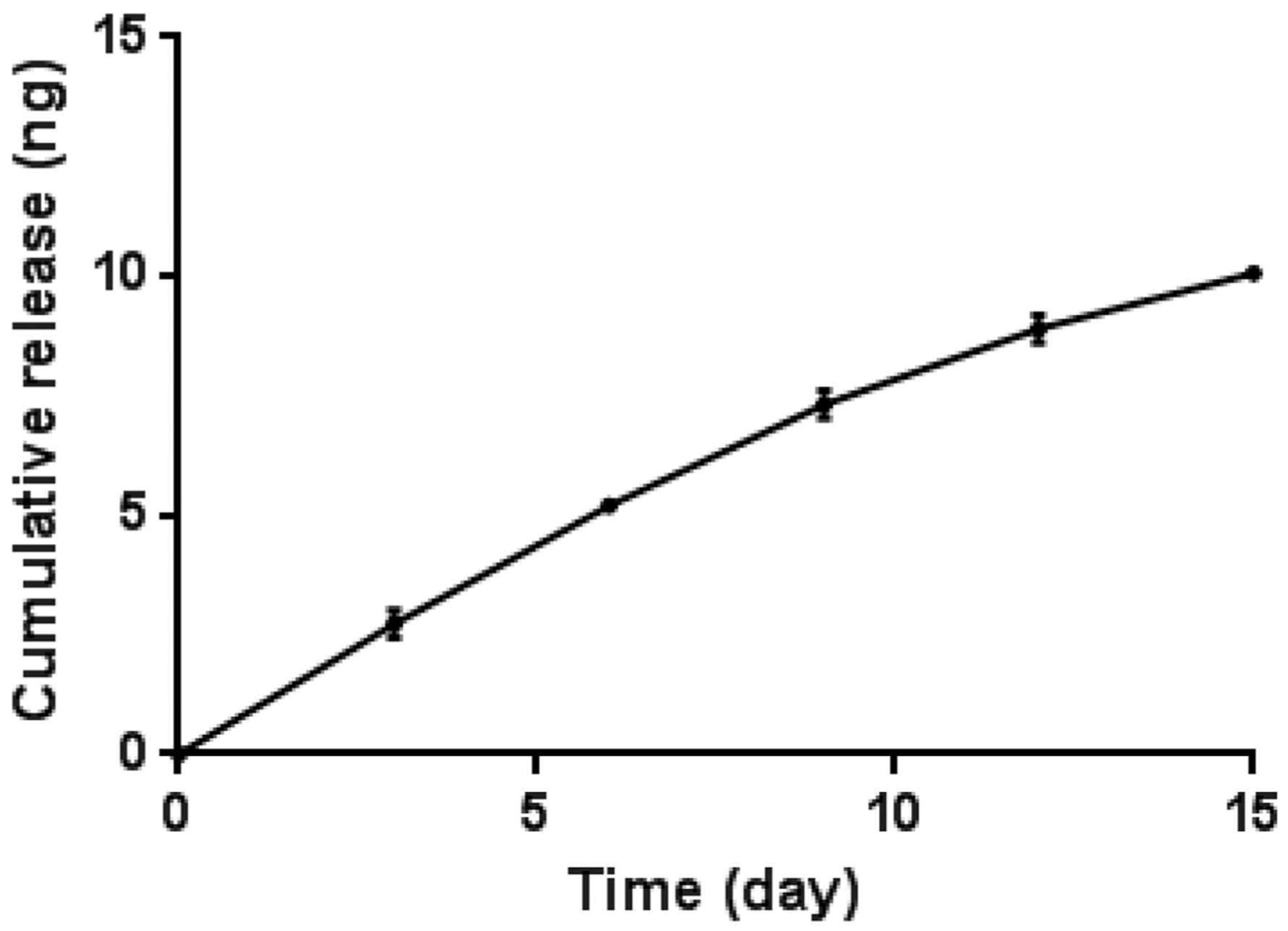

Figure 1.

POCR-16 incubated in a 1:1 volume ratio of milli-Q water and acetonitrile shown to release atRA in a sustained manner. Release for 15 days was observed, with cumulative atRA release amounting to approximately $0.4 \%$ of incorporated atRA. $N=3$, mean \pm SD. 


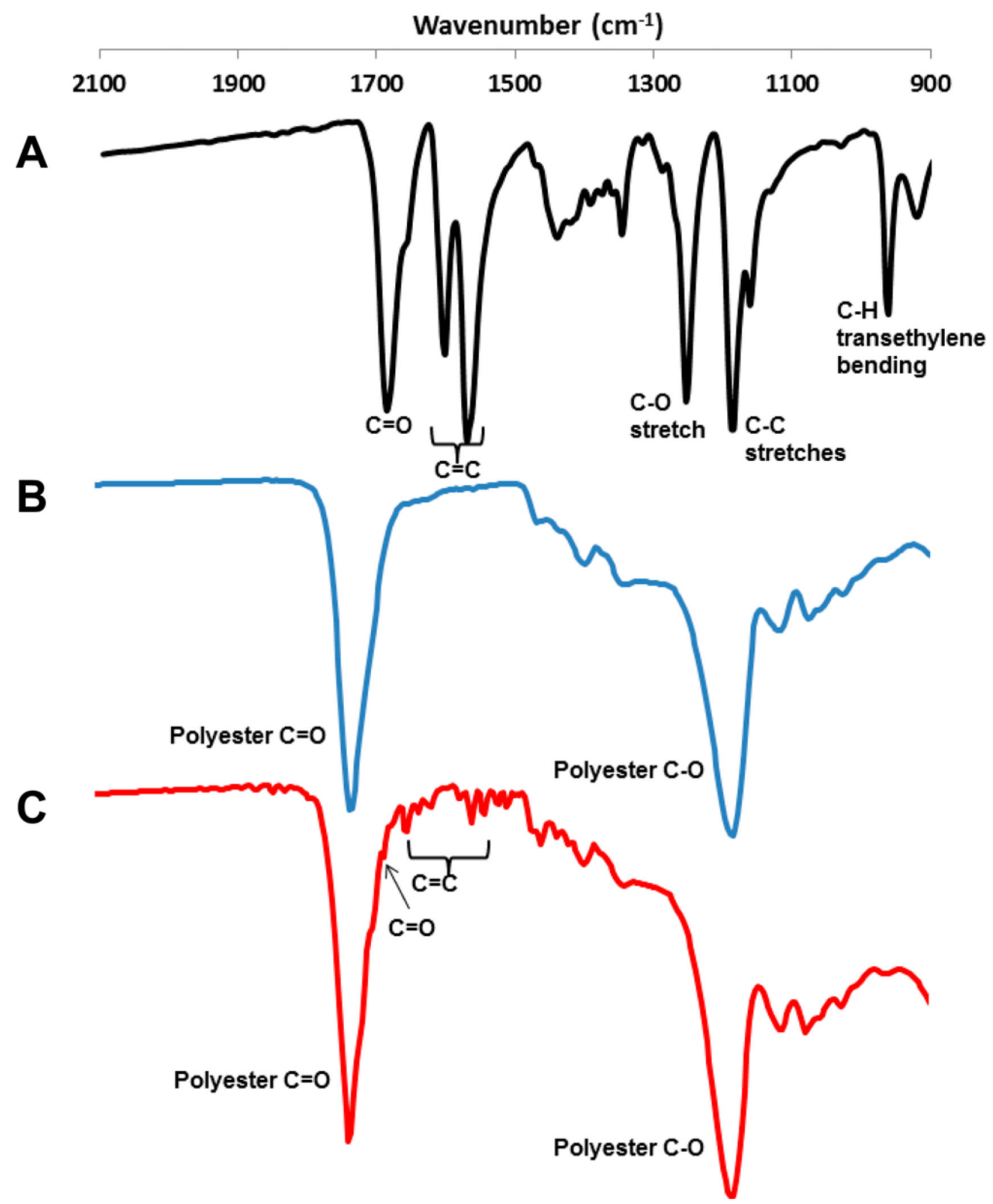

Figure 2.

FTIR spectra of (A) all-trans retinoic acid, (B) poly-(octamethylene-citrate) (POC), and (C) poly(octamethylene-citrate-co-retinate) (POCR-16). For atRA, transmission spectroscopy was used, while for polymer films, attenuated total reflectance FTIR on partially polymerized polymer films $\left(2 \mathrm{~d}, 60^{\circ} \mathrm{C}\right)$ was used. 

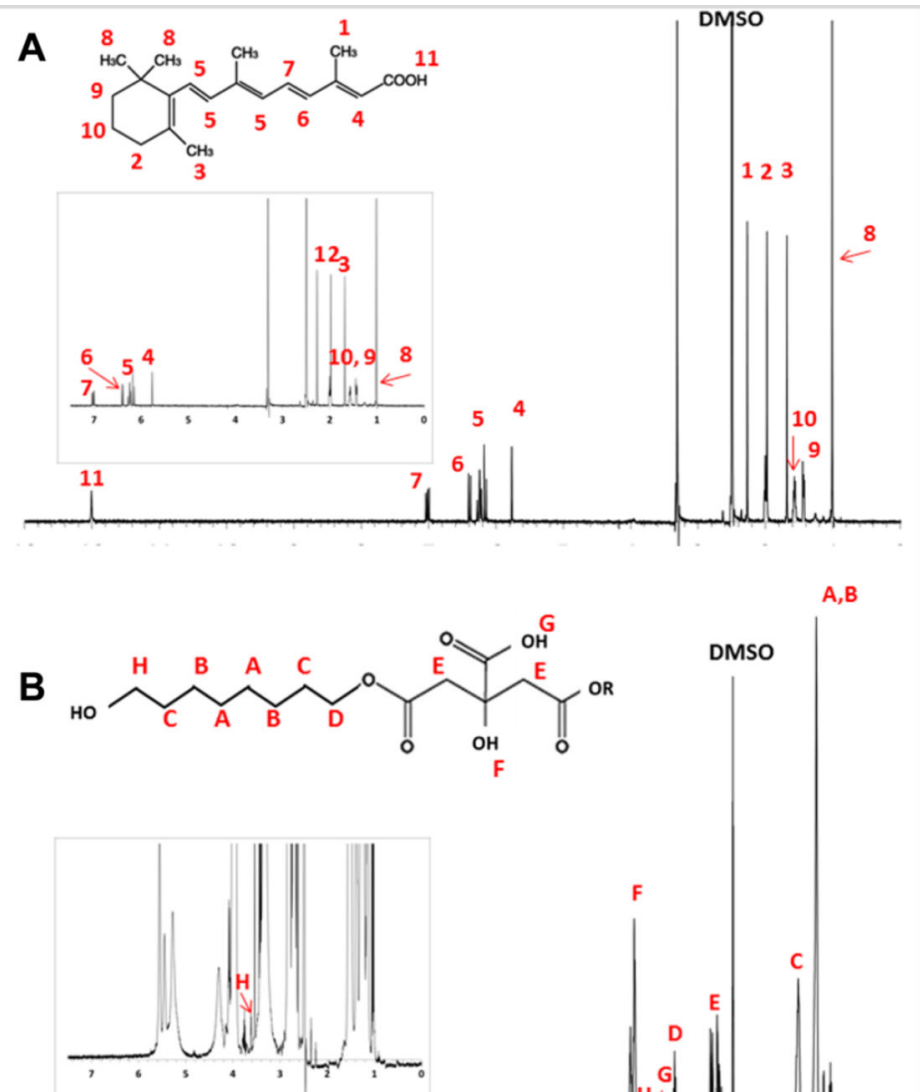

DMSO
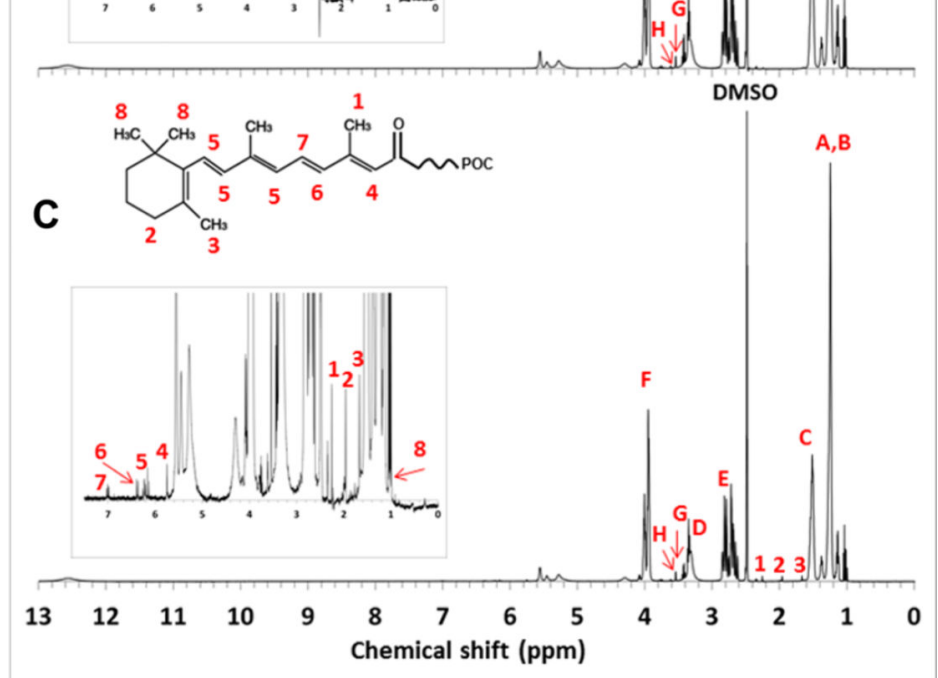

Figure 3.

$\mathrm{H}_{\mathrm{NMR}}$ of (A) atRA, (B) POC, and (C) POCR. Insets are magnified areas showing atRAspecific peaks. For a close-up of the POCR spectrum around 12.0 ppm, see Supporting Information S3B).

ACS Biomater Sci Eng. Author manuscript; available in PMC 2017 February 08. 

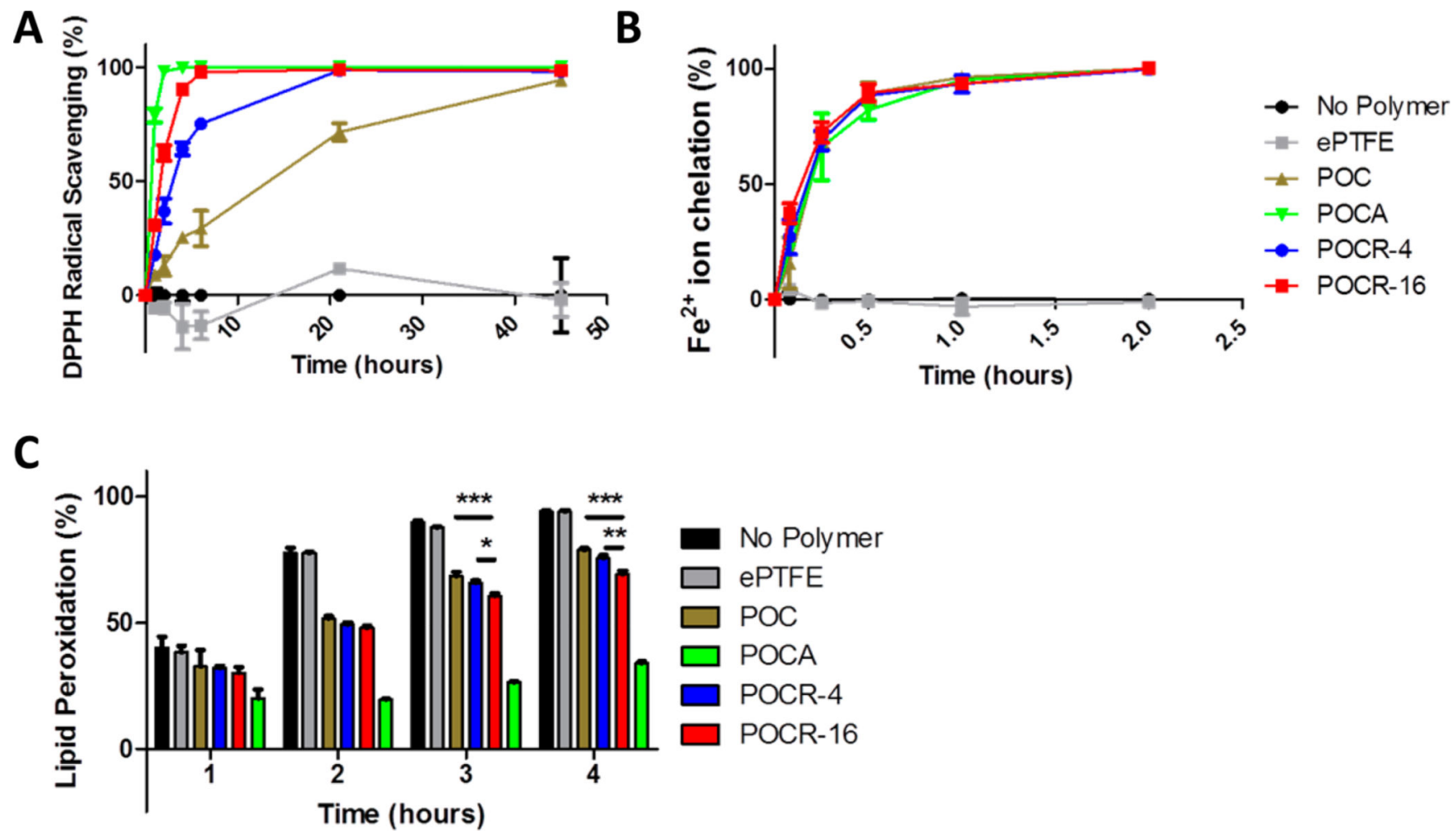

Figure 4.

POCR showing enhanced antioxidant properties relative to POC. (A) Free radical inhibition by POCR is dependent on the atRA content in the polymer as per the DPPH radical scavenging assay. (B) POCR chelates iron ions. (C) The degree of inhibition of lipid peroxidation by POCR is proportional to retinoid content in the polymer. $N=3$, Mean \pm SD. $* p<0.05, * * p<0.01, * * * p<0.001$. 

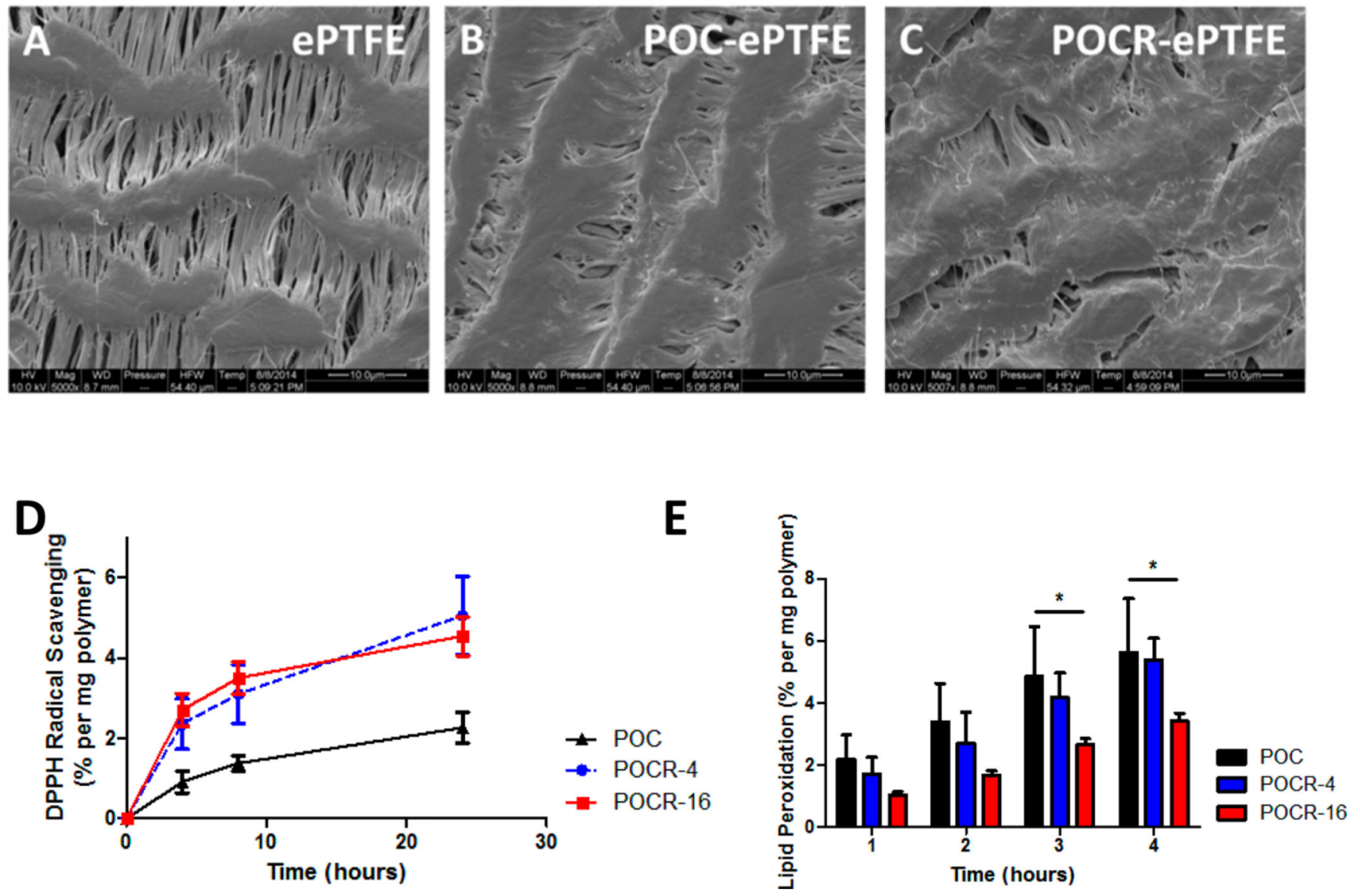

Figure 5.

Scanning electron microscopy (SEM) images and antioxidant characterization of ePTFE vascular grafts coated with POC and POCR. SEM images of (A) ePTFE grafts, (B) POCcoated ePTFE grafts, and (C) POCR-coated ePTFE graft. (D) Increased free radical scavenging by POCR-coated ePTFE grafts relative to POC. (E) POCR-coated ePTFE grafts inhibit lipid peroxidation, and the inhibition depends on the atRA content of the POCR. $N=$ 3 , Mean \pm SD. $* p<0.05, * * p<0.01, * * * p<0.001$. 


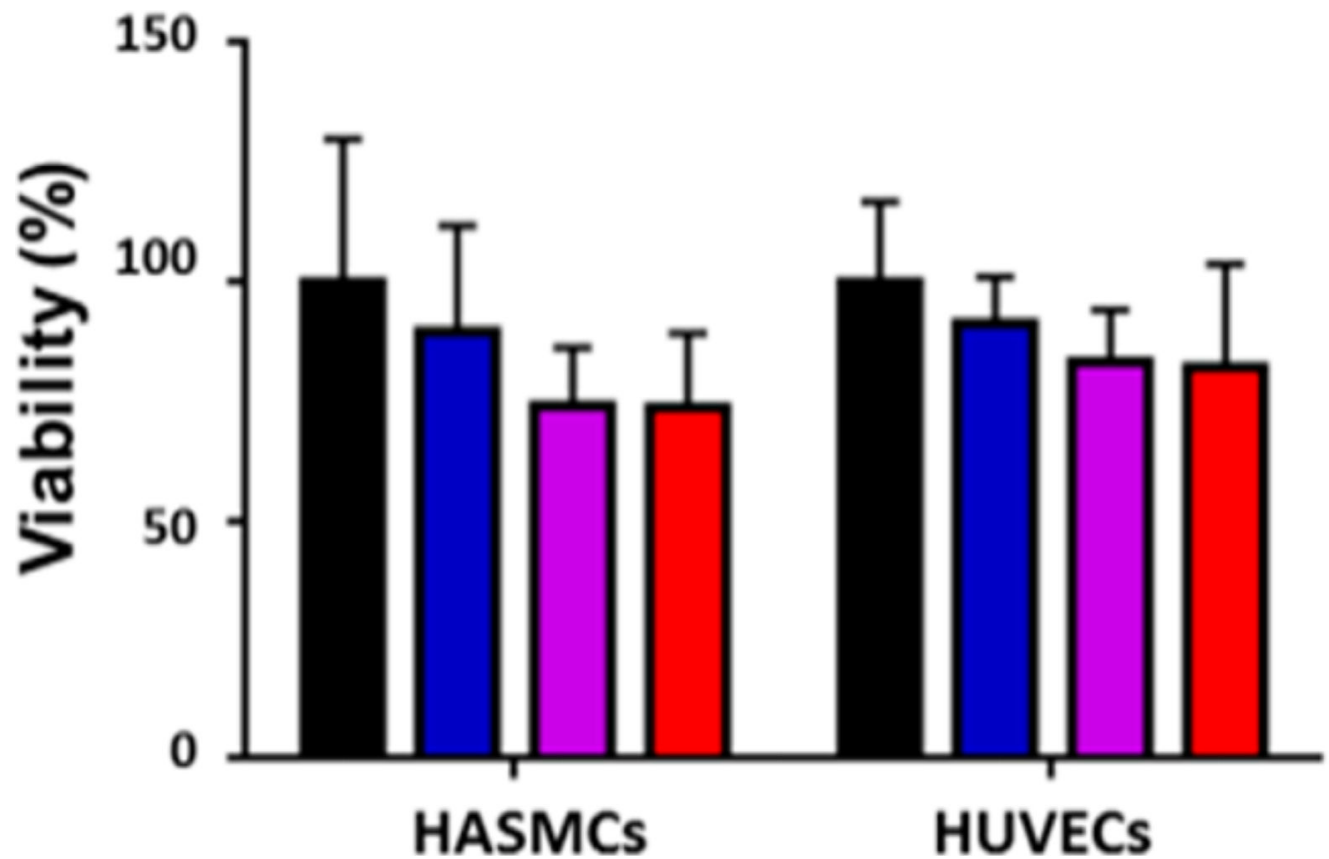

Figure 6.

Graph showing no significant difference in viability observed for both HUVECS and

HASMC cultured on all polymer surfaces. Cells were stained with calcein AM and ethidium homodimer and relative amount of dead cells compared to calcein-positive cells. $N=3$, Mean $\pm \mathrm{SD}, P>0.05$. 
A

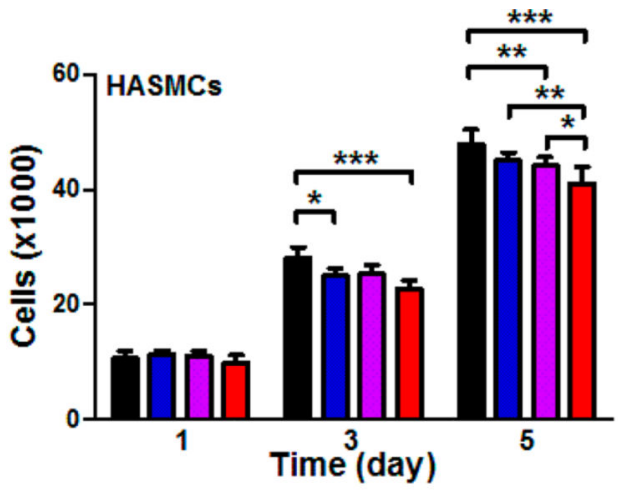

C

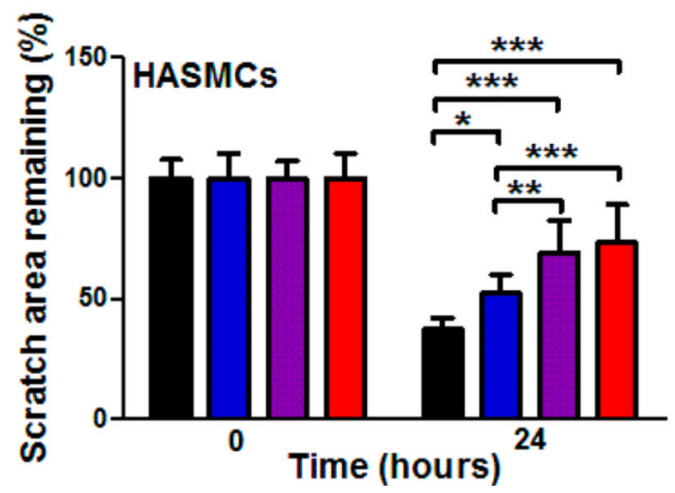

B

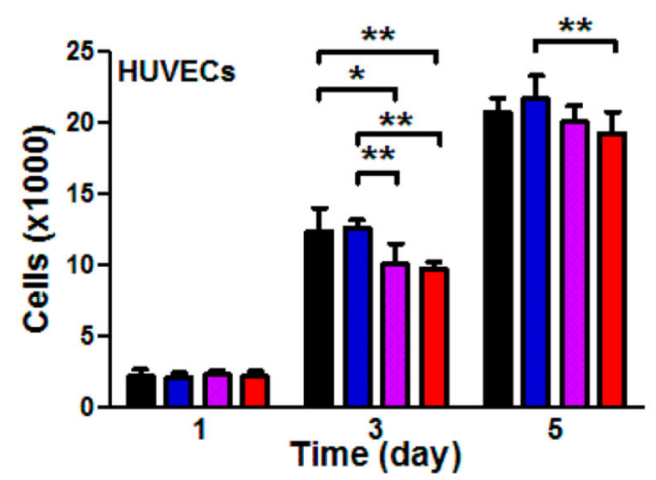

D

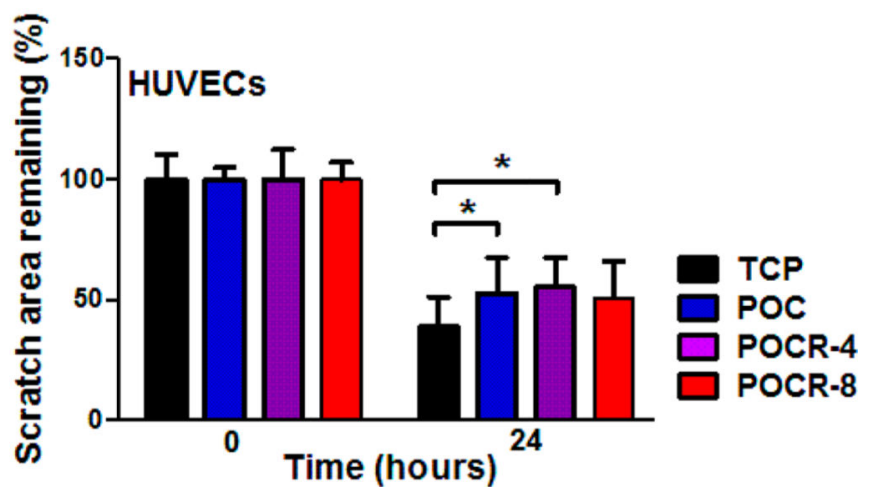

Figure 7.

Effect of POCR with two different atRA contents on the proliferation and migration of HASMC and HUVEC. (A) HASMC proliferation and (B) HUVEC proliferation. $N=4$, Mean \pm SD. $* p<0.05, * * p<0.01, * * * p<0.001$. (C) HASMC migration and (D) HUVEC migration $24 \mathrm{~h}$ postscratch shows selective reduction of HASMC migration only on POCR. $N \geq 7$, Mean \pm SD. $* p<0.05, * * p<0.01, * * * p<0.001$. 
HO<smiles>CC(C)(C)CC(C)(C)O</smiles>

1,8-octanediol

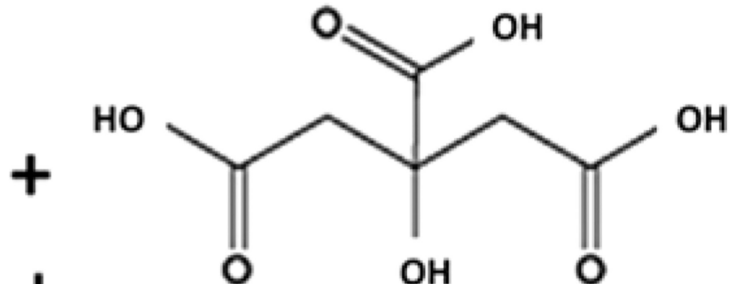

Citric acid

$160 \mathrm{C}, 15 \mathrm{~min}+$

$140 \mathrm{C}, 60 \mathrm{~min}$<smiles>[R20]C(=O)CC([R])(CC(=O)OC(C)(C)[13CH3])C([R])=O</smiles>

Pre-POC

$\mathrm{R}=\mathrm{H}$ or $\sim$<smiles>CC1=C(/C=C/C(C)C/C=C/C(C)=C/C(=O)O)C(C)(C)CCC1</smiles><smiles>[R20]CC(C)([13CH3])OC(=O)CC([R20])(CC([R10])=O)C(=O)O[R10]</smiles>

POCR

$\mathrm{R}_{1}=\mathrm{H}$ or $\sim$

$\mathrm{R}_{2}=\mathrm{H}$ or atRA or $\sim$

Scheme 1.

Synthesis of Poly(1,8-octamethylene-citrate-co-retinate) (POCR)

ACS Biomater Sci Eng. Author manuscript; available in PMC 2017 February 08. 
Table 1

Optimization of Polymerization and atRA Incorporation Conditions ${ }^{a}$

\begin{tabular}{lcll}
\hline conditions & $\begin{array}{c}\text { atRA } \\
\text { recrystallization }\end{array}$ & $\begin{array}{l}\text { polymerization } \\
\text { time }\end{array}$ & $\begin{array}{l}\text { atRA structure } \\
\text { retention }\end{array}$ \\
\hline $\begin{array}{c}60^{\circ} \mathrm{C}, \\
10 \% \mathrm{w} / \mathrm{w}\end{array}$ & yes & 5 days & $\mathrm{nt}$ \\
$37^{\circ} \mathrm{C}$, & yes & 20 days & nt \\
$10 \% \mathrm{w} / \mathrm{w}$ & & & \\
$60{ }^{\circ} \mathrm{C}$, & no & 5 days & yes \\
$30 \% \mathrm{w} / \mathrm{w}$ & & & \\
$37{ }^{\circ} \mathrm{C}$, & no & 20 days & no \\
$30 \% \mathrm{w} / \mathrm{w}$ & & & \\
\hline
\end{tabular}

${ }^{a}$ nt: not tested.

atRA concentration was $4 \mathrm{mg} / \mathrm{mL}$. Structure retention assessed using HPLC. $\mathrm{x} \% \mathrm{w} / \mathrm{w}$ indicates POC concentration in ethanol used. 